\title{
English for Specific Purpose: Revitalizing Climate Change Awareness Using Digital Literacy and Gamification for Engineering Faculty in Papua
}

\author{
Martha Betaubun ${ }^{1 *}$, Nasrawati ${ }^{2}$ \\ 1,2Universitas Musamus, Indonesia
}

Corresponding Author: Martha Betaubun@ marthabetaubun@unmus.ac.id*

\begin{tabular}{|c|c|}
\hline \multirow{10}{*}{$\begin{array}{c}\text { ARTICLE INFO } \\
\text { Article history: } \\
\text { Received } \\
\text { October 29, } 2020 \\
\text { Revised } \\
\text { November 10, } \\
2020 \\
\text { Accepted } \\
\text { December 06, } \\
2020\end{array}$} & ABSTRACT \\
\hline & $\begin{array}{l}\text { The air quality index (AQI) in Papua has the best index among other } \\
\text { provinces in Indonesia. Papua has different geographical and social } \\
\text { conditions than western Indonesia. In particular, forests in Papua are } \\
\text { more numerous with fewer industries and automobiles than provinces in } \\
\text { western Indonesia. The article aims to determine respondents' } \\
\text { perceptions related to climate change awareness and pro-environmental } \\
\text { behavior (PEB) in regions that have AQI in Indonesia, namely Papua. }\end{array}$ \\
\hline & This study uses a survey strategy through a questionnaire instrument for \\
\hline & $\begin{array}{l}\text { students who have received the application of digital literacy and } \\
\text { gamification in the English for Specific Purposes class. The questionnaire }\end{array}$ \\
\hline & was distributed to be filled in by respondents with a total number of \\
\hline & responses totaling 164 responses from students of engineering faculty. \\
\hline & $\begin{array}{l}\text { This study identified that respondents' awareness of climate change was } \\
\text { in the moderately aware category ( } \mathrm{M}=3.8 \text {. These findings are directly }\end{array}$ \\
\hline & proportional to PEB respondents who are at the middle level $(M=3.9)$. \\
\hline & $\begin{array}{l}\text { Furthermore, analysis of the data shows that respondents are highly } \\
\text { aware }(\mathrm{M}=4.3) \text { that humans have a responsibility for climate change, } \\
\text { and respondents are highly concern }(\mathrm{M}=4.4) \text { to carry out forestation } \\
\text { both by individuals and community. The finding implication of this } \\
\text { study is learning through digital literacy and gamification has a positive } \\
\text { potential to be applied through policy and developed into a learning } \\
\text { model to increase awareness of climate change and PEB. }\end{array}$ \\
\hline & $\begin{array}{l}\text { Keywords: Climate Change, Pro-environmental Behavior, Digital Literacy, } \\
\text { Englsih for Specific Puprposes }\end{array}$ \\
\hline How to cite & $\begin{array}{l}\text { Betaubun, M., \& Nasrawati, N. (2020). English for Specific Purpose: Revitalizing } \\
\text { Climate Change Awareness Using Digital Literacy and Gamification for } \\
\text { Engineering Faculty in Papua. Jurnal Iqra': Kajian Ilmu Pendidikan, 5(2). 68-82. } \\
\text { https://doi.org/10.25217/ji.v5i2.1181 }\end{array}$ \\
\hline & http://journal.iaimnumetrolampung.ac.id/index.php/ji/ \\
\hline \multicolumn{2}{|c|}{ This is an open access article under the CC BY SA license } \\
\hline
\end{tabular}

\section{INTRODUCTION}

It has been realized that climate change is occurring, and the circumstances are getting worse day by day. Climate change is conditions that require attention from all walks of life. Climate change is the most essential and critical environmental topic because it deals directly with social, ecological, and health aspects (Bongaarts, 2019). The concentration of $\mathrm{CO}^{2}$ in the atmosphere layer has increased significantly more than $30 \%$ caused by humans and occurred in the last 50 years (Socolow, Hotinski, Greenblatt, \& Pacala, 2004). According to estimates, humans have up to 15 years to make significant changes related to lifestyle to prevent the worse effects of climate 
change (Antilla, 2005). Consensus has been held among experts to take concrete actions to prevent the effects of climate change on social and environmental aspects (Bongaarts, 2019). With the massive movement of climate change information, generally, US citizens are aware of the situation (Tubman, 2015; Waxman et al., 2013). Media support for climate change issues has helped to contribute to awareness of these issues.

The distribution of information related to climate change is not proportionally affected the concern of the community and government to follow up on the issue. The public and decision-makers are lowly motivated to be involved in acting on climate change issues (Moser \& Dilling, 2011). Although there is a better understanding of climate change, it does not automatically lead to transformation in pro-environmental behavior (McKenzie-Mohr, 2008). Surprisingly citizens in emerging countries are more concerned about climate change than citizens from the more prosperous country (Sandvik, 2008). Other findings suggest that women and minority races have more fear of climate change (Kellstedt, Zahran, \& Vedlitz, 2008). The main obstacle to the lack of willingness to act on the issue of climate change inseparable from the polarization of issues that intersect with ideological aspects (Nisbet, 2009), faith, political affiliation, and values (Brody, Zahran, Grover, \& Vedlitz, 2008; Sandvik, 2008). In addition, the issue of climate change is seen as not a problem that is relevant to personal interests (Moser \& Dilling, 2011) which is far from personal concentration in the form of health, family, and finance (Lorenzoni \& Pidgeon, 2006). The finding is corroborated by the traditional mass media which is less useful in igniting immediate action in lifestyle and PEB (Moser \& Dilling, 2011; Prihandoko \& Fitria, 2017).

Research on climate change has been carried out on a massive scale from various disciplines because of the importance of the issue. In this decade, millions of researchers researched this topic. However, research to encourage changes in PEB remains a challenging thing to do. In encouraging behavioural change, several previous studies provide studies related to the use of gamification (Bicen \& Kocakoyun, 2018; Hursen \& Bas, 2019; Panis et al., 2020). Moreover another findings also impliy the encouregment of PEB through gamification (Antwi, Appiahene, \& Boakye-Ansah, 2018; Morganti et al., 2017; Nastis \& Pagoni, 2019; Nor \& Azhar, 2017; Wee \& Choong, 2019). The previous research used gamification that has electronic media-based to instill environmental awareness patterns. Gamification means the use of game elements in non-gaming contexts (Deterding et al., 2011). In general, previous research has focused on the application of the gamification platform to change the subject's behavior related to climate change issues. However, concerning gamification, only a few studies have looked at the perspective of students, in particular, expanding the scope of the influence of the application of digital literacy through gamification on the issue of climate change.

This study aims to explore perspectives related to awareness of climate change and PEB for students who have gained new literacy applications through gamification in ESP classes. New patterns of communication that are more impactful are needed to encourage public involvement on issues of climate change (Fredy et al., 2020; Kellstedt et al., 2008). The perspective exploration of students regarding the application of new literacy through gamification needs to be explored especially for students who live in remote areas, especially in Papua, who have the best AQI among other provinces in Indonesia (Iswari, 2018; Purnamadewi et al., 2019; Susanto et al., 2017). This research will be interesting because the subjects live in areas that are less exposed to pollution - moreover, the number of vehicles and industries relatively low in Papua. The results 
of exploration at the level of awareness of climate change and PEB especially students in the Papua, can be developed into a policy or learning model that emphasizes the strengthening of environmentally conscious behavior to support the prevention of climate change.

The development of the use of technology spread to the various fields, one of which is literacy. Various theories emerged related to the expansion of concepts from literacy. Digital literacy has a dynamic meaning because it is bound to humans that influenced by behavior and personal use (Rowsell et al., 2016). In addition, digital literacy, alongside information literacy and new literacy, are sheltered under the concept of literacies (Machin-Mastromatteo, 2012). Furthermore, cognitive inseparable from digital literacy as a foothold in the ability to think critically to understand and use information in various formats (Chan, Churchill, \& Chiu, 2017). Digital literacy is also seen as a social practice that involves the ability to master digital devices to engage in connection and communication through digital technology (Prihandoko, 2019; Machin-Mastromatteo, 2012; Novakovich, 2016; Tang \& Chaw, 2016). In developing digital literacy capabilities, three stages need to be passed namely digital competence, digital application, and digital transformation (Martin \& Grudziecki, 2006).

The benefits of gamification usage to the issue of climate change noticeably the attention of experts in this decade. Gamification is able to emphasize the essence of urgency, awareness, and desire to act on climate change (Dulic et al., 2011). Gamification can also help overcome factors that prevent the public from taking ecological action (Sgueo, 2017). In addition, gamification can elevate communicationrelated to climate change at different levels by strengthening personal abilities and interests through the help of well-designed technology (Rajanen \& Rajanen, 2019). In addition, through gamification, energy-saving campaigns are believed to run more effectively and meaningfully to motivate and increase user involvement (Wee \& Choong, 2019).

The use of gamification to raise awareness and motivation to act on issues of climate change needs to consider several elements. Game elements need to be related to the user's background to maximize the use of gamification in changing user behavior (Anggawirya \& Prihandoko, 2020; Barata et al., 2013). Another consideration to note is increasing intrinsic motivation for long-term influence is more critical than the extrinsic motivation (Hägglund, 2012). In relation to motivation, the use of gamification can create a pleasant environment to motivate user involvement (Wee \& Choong, 2019). In maintaining the consistency of the drive to change intrinsic motivation, gamification needs to pay attention to the psychological needs of individuals, which include autonomy, relatedness, and competence (Ryan, Rigby, \& Przybylski, 2006).

\section{METHOD}

This research uses a quantitative approach with a survey strategy. The survey strategy, in particular, is quite reliable in taking data from respondents' perceptions data derived from one state university in the province of Papua. Specifically, the data was obtained from the English for Specific Purpose (ESP) class from students in management economics who represent social science disciplines and civil engineering who represent hard science disciplines. An approach of learning with digital literacy through gamification has been applied to the ESP class. Students from the two classes from system information and information technology department received a digital literacy approach using the website climate.nasa.gov and gamification through Kahoot 
to conduct formative assessments. ESP learning on climate change topics took place in two meetings. The material discussed is related to climate change with the theme covering prevention, mitigation, adaptation, environmental education, consumer awareness, and energy efficiency behavior. The outcome of this learning is that students understand the concept, critically evaluate, and conduct a mini-project at the end of the climate change topics.

The random sampling technique is applied to obtain data sourced from four classes. The research instrument in this study has adapted to explore the perspectives of students related to climate change awareness and pro-environmental behavior (Kellstedt et al., 2008; Reynolds et al., 2010). Researchers conducted pilot testing to measure reliability and asked experts from environmental field to validate the instrument. Furthermore, the measurement of reliability and validity was used SPSS 23 software. The results of the reliability test were 0.51 and validity test were 0.72 that can be categorized into reliable and valid instrument. Respondents were asked to answer questions according to their perception. In the questionnaire, respondents are also required to fill in gender and ethnicity. The questionnaire related to climate change awareness consists of 17 questions with five points Likert scale and two questions to determine the most causes and impacts of climate change. The instrument related to pro-environmental behavior consists of 17 questions with five points Likert scale and three questions related to the actions most desired to be carried out by individuals, governments, and communities to act in preventing climate change. The questionnaire was translated into Indonesian and distributed via Google Form. The questionnaire was distributed to students for two weeks. Total responses obtained from questionnaires distributed amounted to 80 responses from social science disciplines and 122 responses from scientific disciplines.

The responses that have been collected were processed by various processes. The response comes from the Google Form exported into the .xls format for data analysis. Data is processed by finding the mean and frequency using SPSS 23. The processed data is displayed in a quantitative descriptive presentation. Two interpretation frameworks were applied to the data results. In the climate change awareness variable, the framework is applied to the mean range of 1.0-3.0 = lowly aware, 3.1-4.0= moderately aware, 4.1-5.0 = highly aware. Whereas in the pro-environmental behavior variable, the framework applied in the range of mean 1.0-3.0 = lowly concern, 3.1-4.0 = moderately concern, 4.1-5.0 = highly concern.

\section{RESULT AND DISCUSSION}

Based on Table 1, the results of data related to awareness of climate change vary based on questionnaires that have been distributed to students. The data in the table presented does not yet display the perspective of students according to gender and scientific discipline. In general, respondents' perceptions related to the impacts of climate change, especially those aspects correlated to the effects of climate change and warming on individuals, the economic-financial situation, and the community, are categorized as moderately aware $(\mathrm{M}=4.0)$. On the other hand, an interesting finding reflected in this table is that respondents are highly aware $(\mathrm{M}=4.3)$ related to humans being very closely involved and responsible for climate change.

Table 1. Climate change perspective 
English for Specific Purpose: Revitalizing Climate Change Awareness Using Digital Literacy and Gamification for Engineering Faculty in Papua

\begin{tabular}{|l|l|l|}
\hline Responses & Mean & SD \\
\hline $\begin{array}{l}\text { Climate change will harm my health in the next 25 } \\
\text { years. }\end{array}$ & 4.1 & 1 \\
\hline $\begin{array}{l}\text { Climate change will harm my economic and } \\
\text { financial situation in the next 25 years. }\end{array}$ & 3.8 & 1.2 \\
\hline $\begin{array}{l}\text { Climate change will harm the environment where } \\
\text { my family and I live. }\end{array}$ & 4 & 1.1 \\
\hline Humans are responsible for climate change. & 4.3 & 0.9 \\
\hline $\begin{array}{l}\text { Climate change have a significant impact on public } \\
\text { health in my country. }\end{array}$ & 3.6 & 1.1 \\
\hline $\begin{array}{l}\text { Climate change have a significant impact on } \\
\text { economic development in my country. }\end{array}$ & 3.6 & 1 \\
\hline $\begin{array}{l}\text { Climate change have a significant impact on the } \\
\text { environment in my country. }\end{array}$ & 3.8 & 1.2 \\
\hline Auto-mobiles contribute to climate change. & 4.2 & 0.8 \\
\hline The industry contributes to climate change. & 4.2 & 1.3 \\
\hline Climate change are caused by air pollution. & 4.1 & 1.2 \\
\hline Fossil fuels are the cause of climate change. & 3.6 & 1.3 \\
\hline Climate change are caused by deforestation. & 4.2 & 0.8 \\
\hline $\begin{array}{l}\text { Agricultural problems and hunger are the results of } \\
\text { climate change. }\end{array}$ & 3.4 & 1.1 \\
\hline $\begin{array}{l}\text { The increased amount of people with skin cancer is } \\
\text { a result of climate change. }\end{array}$ & 3.5 & 1.2 \\
\hline Climate change are causing ecological disasters. & 3.6 & 1.1 \\
\hline Climate change affect the sea-level rise. & 3.9 & 1.1 \\
\hline $\begin{array}{l}\text { Climate change are increasing rainfall and } \\
\text { humidity. }\end{array}$ & 3.3 & 1.2 \\
\hline
\end{tabular}

Respondents' perspectives related to the impact of climate change in the country where the respondent lives belong to the moderately aware category $(M=3.7)$. The Papua Provision, specifically the city of Merauke has natural conditions that are quite different in character from other regions in Indonesia, especially in the west. Respondents have the view that the effects of global warming, in general, do not have an impact on public health. Respondents also view the economic sector and the environmental sector especially in Papua as not too affected by climate change $(\mathrm{M}=$ 3.6).

Table 2. The causes of climate change rank

\begin{tabular}{|l|c|c|}
\hline \multicolumn{1}{|c|}{ Causes } & Scores & Rank \\
\hline Automobiles & 48 & 1 \\
\hline Deforestation & 44 & 2 \\
\hline Industry & 32 & 3 \\
\hline Air pollution & 28 & 4 \\
\hline Fossil fuels & 12 & 5 \\
\hline
\end{tabular}


The overall response to questions related to the causes of climate change is excellent. On average, in Table 1, respondents are highly aware of the factors that contribute to climate change $(M=4.1)$. Respondents have strong beliefs related to the causes of climate change that cannot be separated from automobiles, industry, and deforestation $(\mathrm{M}=4.2)$. The data in Table 1 is in line with the findings in Table 2 regarding the ranking of contributors to climate change chosen by respondents. Automobiles are seen as a significant contributor. Further occupying the next position, respondents chose deforestation and industry. On the other hand, respondents have moderately aware of perception related to the impact of air pollution and fossil fuels on climate change which are also in line with the findings in Table 2 (Rank 4 and 5).

Table 3. The impacts of climate change rank

\begin{tabular}{|l|c|c|}
\hline Impact & Scores & Rank \\
\hline Sea-level rise & 42 & 1 \\
\hline Ecological disasters & 36 & 2 \\
\hline Skin cancer & 32 & 3 \\
\hline Agricultural problems and starvation & 28 & 4 \\
\hline Increased rainfall & 26 & 5 \\
\hline
\end{tabular}

The average level of respondent awareness related to the impact of climate change is in the moderately aware category $(M=3.5)$. The impact that mostly felt by respondents was sea-level rise $(M=3.9)$. Respondents also realized that Ecological disaster and skin cancer are impacts that arise from climate change $(\mathrm{M}=3.6)$. The impact of data from climate change in Table 1 is supported by the findings in Table 3. Respondents have the majority view regarding sea-level rise as the most impactful that felt by respondents. Furthermore, the impact in the form of the ecological disaster was also taken seriously by respondents after the sea level rise. In addition, skin cancer is seen as a more severe impact rather than agricultural problems \& starvation and increased rainfall (Rank 4 \& 5).

Table 4. Personal Efficacy and Pro-Environmental Behavior Perspective

\begin{tabular}{|l|l|l|}
\hline Responses & Mean & SD \\
\hline I believe my actions influence climate change. & 3.5 & 1.1 \\
\hline $\begin{array}{l}\text { I believe in reducing the use of automobiles helps } \\
\text { prevent climate change. }\end{array}$ & 3.9 & 1.2 \\
\hline $\begin{array}{l}\text { I believe that climate change can be prevented } \\
\text { through recycling activities. }\end{array}$ & 3.3 & 1.3 \\
\hline $\begin{array}{l}\text { I believe that Energy-saving prevents climate } \\
\text { change. }\end{array}$ & 3.3 & 1.4 \\
\hline $\begin{array}{l}\text { I believe that the use of alternative energy } \\
\text { prevents climate change. }\end{array}$ & 4 & 1 \\
\hline $\begin{array}{l}\text { I believe that climate change can be prevented } \\
\text { through planting trees/plants }\end{array}$ & 4.4 & 0.9 \\
\hline $\begin{array}{l}\text { I suggest that the government should reduce } \\
\text { emissions from automobiles to prevent climate } \\
\text { change. }\end{array}$ & 3.9 & 1.1 \\
\hline
\end{tabular}


English for Specific Purpose: Revitalizing Climate Change Awareness Using Digital Literacy and Gamification for Engineering Faculty in Papua

\begin{tabular}{|l|l|l|} 
I suggest that governments can prevent climate & 3.2 & 1.4 \\
change by promoting alternative energy use. & 3.2 & 1 \\
\hline $\begin{array}{l}\text { I suggest that issuing environmental laws can be } \\
\text { taken by the government to prevent climate } \\
\text { change }\end{array}$ & 4.1 & \\
\hline $\begin{array}{l}\text { I suggest that the government should initiate to } \\
\text { recycle the program to prevent climate change and } \\
\text { climate change. }\end{array}$ & 3.5 & 1.3 \\
\hline $\begin{array}{l}\text { I suggest that reducing industrial emissions can be } \\
\text { done by governments to prevent climate change. }\end{array}$ & 4.2 & 1 \\
\hline $\begin{array}{l}\text { My actions to reduce the effects of climate change } \\
\text { in my community will encourage others to reduce } \\
\text { the effects of global warming through their } \\
\text { actions. }\end{array}$ & 4.4 & 0.8 \\
\hline $\begin{array}{l}\text { The public should use energy conservation } \\
\text { measures to prevent climate change. }\end{array}$ & 4.2 & 0.7 \\
\hline $\begin{array}{l}\text { Planting trees can be done by the community to } \\
\text { prevent climate change. }\end{array}$ & 4.5 & 0.7 \\
\hline $\begin{array}{l}\text { Society can prevent climate change by reducing } \\
\text { the use of fossil fuels. }\end{array}$ & 3.4 & 1.3 \\
\hline $\begin{array}{l}\text { Implementation of a community-recycling } \\
\text { program can prevent climate change. }\end{array}$ & 3.7 & 1.1 \\
\hline $\begin{array}{l}\text { The community can prevent climate change by } \\
\text { stopping pollution from factories. }\end{array}$ & 4.2 & 0.9 \\
\hline
\end{tabular}

Table 5. Individual's perception of PEB rank

\begin{tabular}{|l|l|l|}
\hline Action & Scores & Rank \\
\hline Forestation & 46 & 1 \\
\hline Alternative energy usage & 36 & 2 \\
\hline Automobiles usage reduction & 30 & 3 \\
\hline Energy saving & 28 & 4 \\
\hline Recycling activities & 24 & 5 \\
\hline
\end{tabular}

Respondents' perspectives regarding personal efficacy and PEB are presented in Table 4. On average, respondents had a moderate level of personal efficacy and proenvironmental behavior perspective $(\mathrm{M}=3.9)$. There are interesting findings from the data in Table 4 regarding the rate of highly concern by individuals related to the forestation program. Respondents' perceptions indicate in preventing climate change through forestation $(M=4.4)$ and alternative energy usage $(M=4.0)$. Respondents also have the perception to reduce the use of automobiles to prevent climate change. Meanwhile, recycling and energy-saving activities are seen as the last option. These findings are in line with the findings in Table 5. Respondents prefer and are motivated by the forestation approach rather than alternative energy usage. On the other hand, reducing the use of automobiles is preferred (Rank 3) rather than energy-saving and recycling activities. 
English for Specific Purpose: Revitalizing Climate Change Awareness Using Digital Literacy and Gamification for Engineering Faculty in Papua

Table 6. Individual's perceptions of government in PEB

\begin{tabular}{|l|l|l|}
\hline Action & Scores & Rank \\
\hline Reducing industrial emissions & 42 & 1 \\
\hline Issuing environmental laws & 38 & 2 \\
\hline Reducing automobiles emissions & 32 & 3 \\
\hline Recycling program & 30 & 4 \\
\hline Using alternative energy & 22 & 5 \\
\hline
\end{tabular}

Apart from personal motivation, in Table 4, respondents have moderately concerns related to suggesting the government act to prevent climate change $(M=3.9)$. Respondents have high concern to urge the government for the reduction of industry emissions $(M=4.2)$ followed by the issuance of regulations related to the environment $(\mathrm{M}=4.1)$ to prevent climate change. The respondent's perspective is strengthened by the ranking data in Table 6 . Respondents prefer to encourage the government to reduce emissions in the industrial world (Rank 1). Moreover, respondents prefer the government to issue environmental laws instead of the reduction of automobile emissions. Programs in the form of recycling and alternative energy use are less attractive to respondents (Rank $4 \& 5$ ).

Table 7. Individual perception of the community in PEB rank

\begin{tabular}{|l|r|c|}
\hline Action & Scores & Rank \\
\hline Forestation & 46 & 1 \\
\hline Energy conservation & 34 & 2 \\
\hline Discontinuing factory pollution & 32 & 3 \\
\hline Recycling program & 28 & 4 \\
\hline Reducing fossil fuels & 24 & 5 \\
\hline
\end{tabular}

In addition, regarding the perspective of respondents in the PEB-related community in Table 5, the average respondent is highly concern $(M=4.1)$ to encourage the community to act in PEB. Respondents are highly concern $(\mathrm{M}=4.4)$ related to the actions of respondents in inspiring the community to prevent climate change. Moreover, Respondents are highly concern $(\mathrm{M}=4.5)$ in encouraging communities to act through forestation actions. Respondents' concerns related to energy conservation and factory emission cessation programs $(\mathrm{M}=4.2)$, while the recycling and fossil fuel reduction program were classified tobe moderately concern by respondents $(M=3.6)$. The data in Table 5 is strengthened by the findings in the data in Table 7. Forestation occupies the highest position related to the actions suggested by respondents to the community, followed by energy conservation (Rank 2). Meanwhile, respondents also encouraged the community to stop industrial pollution followed by recycling programs and the reduction of fossil fuels (Rank $4 \& 5$ ).

Table 8. Climate Change Awareness and PEB based on gender and disciplines

\begin{tabular}{|l|c|c|c|c|}
\hline \multirow{2}{*}{ Categories } & \multicolumn{2}{|l|}{ Social Science } & \multicolumn{2}{l|}{ Hard Science } \\
\cline { 2 - 5 } & Male & Female & Male & Female \\
\hline Climate Change Awareness & 3.6 & 4 & 3.7 & 4 \\
\hline Pro Environmental Behavior & 3.8 & 3.8 & 3.9 & 3.9 \\
\hline
\end{tabular}


This research tries to develop different views related to climate change awareness and PEB by including gender and scientific disciplines, as presented in Table 8. On average women from social science and hard science disciplines have a better awareness of climate change $(M=4)$ than men $(M=3.7)$ have. On the other hand, the finding of awareness index is not identical to the attitude of PEB in which women and men are moderately concern both in the social sciences $(\mathrm{M}=3.8)$ and hard science (3.9). There was no significant difference in PEB between the two genders in the hard science and social sciences $(\mathrm{M}=3.8, \mathrm{M}=3.9)$. Furthermore, based on the data, it can be seen that respondents from the hard science discipline have a better index of awareness of climate change $(\mathrm{M}=3.9)$ and PEB $(\mathrm{M}=3.9)$ compared to the respondents from social science $(\mathrm{M}=3.8 \& \mathrm{M}=3.8)$.

The objective of this study initially explored respondents' level of awareness of climate change. Respondents' perceptions are explored after the application of digital literacy-based learning using gamification in ESP classes in economics-management and civil engineering class. The finding based on this study was respondents are moderately aware of the effects of climate change. The unexpected finding was that respondents are highly aware that humans are responsible for climate change. What is surprising is that respondents have a medium level of awareness related to the impact of climate change on the economic and environmental sectors where the respondent lives, namely Papua. Along with these findings, previous studies have described that there is a correlation between race and ethnicity in minority environments that have a higher awareness of global warming (Schuldt \& Pearson, 2016). It is possible the cause of this finding is the environment in which the respondent lives do not intersect with a large number of industries and automobiles.

Other results from this study also indicate that respondents have a high level of awareness of the factors that contribute to climate change. Respondents have the perception that automobiles, industry, and deforestation are the leading causes of exacerbating climate change. There are similarities related to the findings from this study with the findings from previous studies which stated that automobiles, industry, and deforestation have an impact on global warming (Hogarth, 2017; Olanrewaju, Tilakasiri, \& Bello, 2018). The reason for the respondents having such awareness level is probably caused by the application digital literacy guided by gamification to which is proven to strengthen the level of awareness related to environmental issues as well as to change individual behavior (Morganti et al., 2017).

The findings reflected the usefulness of digital literacy to increase the awareness of climate change. The concept of digital literacy and mastery of these abilities is interpreted differently by several experts. Digital literacy is the ability of individuals to use digital devices and facilities to identify, process, evaluate digital sources to create new content that is communicated through certain specific contexts with others (Tang \& Chaw, 2016). Meanwhile, other approaches to mastering digital literacy are pursued through a five-skill conceptual model consisting of photo visuals, reproductive, branching, information, and emotional photo literacy (Eshet, 2004; Prihandoko, Nurkamto, Marmanto, 2018). In addition, components that need to be mastered to have digital literacy capabilities include operational, formal, information, strategic, communication, and content creation capabilities (Van Deursen, 2010).

The high level of respondent awareness related to factors causing climate change is not in line with the findings on the impacts that are classified as medium. Furthermore, respondents are quite aware that sea-level rise and ecological disaster are the impacts that are felt by respondents due to climate change. There is a consistency 
between the results of this study and previous studies. Previous studies (Bhattachan et al., 2018; Marino, 2018; Morrison, 2017) discuss the sea-level rise and ecological disasters that have a direct impact on the human environment.

The following objective of this research is to find out respondents' perceptions related to PEB. Respondents' highly aware that humans are responsible for climate change is not directly affected to PEB, which is classified as medium. More detailed, the findings of this study are in-line with previous studies (Carfora, Caso, Sparks, \& Conner, 2017; Grønhøj \& Thøgersen, 2017; Pothitou, Hanna, \& Chalvatzis, 2016). However, the results of the data show that respondents show high concern towards forestation programs to help prevent climate change. The high level of concern is predicted from the results of the application of gamification which has a positive influence on behavior change (Wee \& Choong, 2019). Meanwhile, the recycling program was seen as less popular to be carried out by respondents.

Other findings from this study also indicate that respondents have a medium concern related to attitudes that respondents suggest for the government to do. There is a different attitude in the respondent's perception that the respondent has a high concern attitude to ask the government to take action in the form of reducing industrial emissions and issuing environmental laws. On the other hand, respondents have sufficient concern for the use of alternative energy and the recycling program. The findings are different from the caring attitude that respondents expect from the community. Respondents have a high concern attitude to encourage the community to act on the issue of climate change compared to the government. Respondents are highly concerned about encouraging the community to implement the program. This is in line with previous research (Jakučionytè-Skodienė, Dagiliūtè, \& Liobikienė, 2020; Wi \& Chang, 2019) which found that PEB can be promoted through the community. The highly concern index related to encouragement to the community to carry out forestation programs might be influenced by the application of gamification that can attract and motivate users (Morganti et al., 2017).

There are additional findings from this study by including elements of gender and scientific disciplines. In general, women have a higher awareness of climate change than men from both the social and scientific disciplines. These findings broadly support the findings of previous studies which stated that women have a better awareness of climate change than men (Tewari, Singh, \& Verma, 2019; Yadav \& Lal, 2018). The study also revealed that awareness of climate change is not directly proportional to the attitude of PEB, where the findings are unisex and multidisciplinary. On the other hand, respondents in hard science disciplines have a higher level of awareness and concern for climate change than respondents from social science disciplines. This is likely to occur because academic performance can also affect attention to climate change issues (Shi, Visschers, Siegrist, \& Arvai, 2016).

Based on the results obtained from this study, there are several implications that can be applied for the higher education. Policies in the form of focusing learning on the issue of global warming awareness can be applied especially to universities through various different approaches, including environmental literacy and gamification. In addition, the results of learning models can be developed to increase awareness of climate change which also encourage the action of PEB. With the intervention to increase awareness of the environment, students are expected to become initiators of change in environmental conservation. 
English for Specific Purpose: Revitalizing Climate Change Awareness Using Digital Literacy and Gamification for Engineering Faculty in Papua

\section{CONCLUSION}

This study generally found that the level of alertness to climate change among students in Papua who had taken ESP classes by applying digital literacy and gamification was moderate. Besides that, there is a correlation between the level of student awareness with the level of student PEB that is moderate. The results of this study indicate the initial findings that the application of digital literacy and gamification is limited to two meetings in the ESP class resulting in moderate awareness and PEB. This research underscores the potential usefulness of digital literacy and gamification to increase awareness and awareness of being able to act in relation to environmental issues. The limitation of this research is the application of digital literacy and gamification that is only done at two meetings. Further research can assess the long-term effects of applying digital literacy and gamification applied to ESP classes with environmental themes. Another possibility of further research could be to develop learning models that emphasize the element of digital literacy with the use of gamification, especially in learning ESP with environmental themes in order to increase student awareness and concern to act on issues of climate change.

\section{ACKNOWLEDGEMENT}

The authors extend gratitude to Prof. Dr. Philipus Betaubun, M.T as Rector of Universitas Musamus Merake.

\section{AUTHOR CONTRIBUTION STATEMENT}

The authors of this paper are Martha Betaubun (MB) and Nasrawati (NW). MB conducts the data collection, data analysis, and article writing. Meanwhile, NW conducts article writing.

\section{REFERENCES}

Anggawirya, A. M., \& Prihandoko, L. A. (2020). A Voyage to Lilliput of Gulliver's Travel: Environmental Hedonism. ELS Journal on Interdisciplinary Studies in Humanities, 3(1), 110-121. Google Scholar

Antilla, L. (2005). Climate of scepticism: US newspaper coverage of the science of climate change. Global environmental change, 15(4), 338-352. https:// doi.org/10.1016/j.gloenvcha.2005.08.003

Antwi, M., Appiahene, P., \& Boakye-Ansah, Y. A. (2018). Promoting Afforestation for Sustainable Communities through Gamification. Journal of Energy and Natural Resource Management (JENRM), 1(2). https:/ / doi.org/10.26796/jenrm.v1i2.130

Barata, G., Gama, S., Jorge, J., \& Gonçalves, D. (2013, September). Engaging engineering students with gamification. In 2013 5th International Conference on Games and Virtual Worlds for Serious Applications (VS-GAMES) (pp. 1-8). IEEE. Google Scholar

Bhattachan, A., Jurjonas, M. D., Moody, A. C., Morris, P. R., Sanchez, G. M., Smart, L. S., ... \& Seekamp, E. L. (2018). Sea level rise impacts on rural coastal socialecological systems and the implications for decision making. Environmental Science E Policy, 90, 122-134. https:/ / doi.org/10.1016/j.envsci.2018.10.006

Bicen, H., \& Kocakoyun, S. (2018). Perceptions of students for gamification approach: Kahoot as a case study. International Journal of Emerging Technologies in Learning (iJET), 13(02), 72-93. Google Scholar 
English for Specific Purpose: Revitalizing Climate Change Awareness Using Digital Literacy and Gamification for Engineering Faculty in Papua

Bongaarts, J. (2019). Intergovernmental panel on climate change special report on global warming of $1.5^{\circ} \mathrm{C}$ Switzerland: IPCC, 2018. Population and Development Review, 45(1), 251-252. https:// doi.org/10.1111/padr.12234

Brody, S. D., Zahran, S., Grover, H., \& Vedlitz, A. (2008). A spatial analysis of local climate change policy in the United States: Risk, stress, and opportunity. Landscape and urban planning, 87(1), 33-41. https:// doi.org/10.1016/j.landurbplan.2008.04.003

Carfora, V., Caso, D., Sparks, P., \& Conner, M. (2017). Moderating effects of proenvironmental self-identity on pro-environmental intentions and behaviour: A multi-behaviour study. Journal of Environmental Psychology, 53, 92-99. https:// doi.org/10.1016/j.jenvp.2017.07.001

Chan, B. S. K., Churchill, D., \& Chiu, T. K. F. (2017). Digital literacy learning in higher education through digital storytelling approach. Journal of International Education Research (JIER), 13(1), 1-16. https:/ / doi.org/10.19030/jier.v13i1.9907

Deterding, S., Dixon, D., Khaled, R., \& Nacke, L. (2011, September). From game design elements to gamefulness: defining" gamification". In Proceedings of the 15th international academic MindTrek conference: Envisioning future media environments (pp. 9-15). Google Scholar

Dulic, A., Schroth, O., Shirley, M., \& Sheppard, S. (2011, October). Future delta motivating climate change action grounded in place. In International Conference on Entertainment Computing (pp. 228-234). Springer, Berlin, Heidelberg. https://doi.org/10.1007/978-3-642-24500-8_24

Eshet, Y. (2004). Digital literacy: A conceptual framework for survival skills in the digital era. Journal of educational multimedia and hypermedia, 13(1), 93-106. Google Scholar

Fredy, F., Prihandoko, L. A., \& Anggawirya, A. M. (2020). The Effect of Learning Experience on the Information Literacy of Students in the Ri-Png Border During Covid-19 Period. International Journal of Multicultural and Multireligious Understanding, 7(10), 171-180. Google Scholar

Grønhøj, A., \& Thøgersen, J. (2017). Why young people do things for the environment: The role of parenting for adolescents' motivation to engage in pro-environmental behaviour. Journal of Environmental Psychology, 54, 11-19. https:// doi.org/10.1016/j.jenvp.2017.09.005

Hägglund, P. (2012). Taking gamification to the next level. Google Scholar

Hogarth, J. R. (2017). Evolutionary models of sustainable economic change in Brazil: No-till agriculture, reduced deforestation and ethanol biofuels. Environmental innovation and societal transitions, 24, 130-141. https:// doi.org/10.1016/j.eist.2016.08.001

Hursen, C., \& Bas, C. (2019). Use of gamification applications in Science Education. International Journal of Emerging Technologies in Learning (iJET), 14(01), 4-23. Google Scholar

Iswari, L. (2018). Indexing the Environmental Quality Performance Based on A Fuzzy Inference Approach. MSEE, 325(1), 012009. Google Scholar

Jakučionytė-Skodienė, M., Dagiliūtè, R., \& Liobikienė, G. (2020). Do general proenvironmental behaviour, attitude, and knowledge contribute to energy savings and climate change mitigation in the residential sector? Energy, 193, 116784. https:// doi.org/10.1016/j.energy.2019.116784

Kellstedt, P. M., Zahran, S., \& Vedlitz, A. (2008). Personal efficacy, the information environment, and attitudes toward global warming and climate change in the 
English for Specific Purpose: Revitalizing Climate Change Awareness Using Digital Literacy and Gamification for Engineering Faculty in Papua

United States. Risk Analysis: An International Journal, 28(1), 113-126. https:// doi.org/10.1111/j.1539-6924.2008.01010.x

Lorenzoni, I., \& Pidgeon, N. F. (2006). Public views on climate change: European and USA perspectives. Climatic Change, 77(1-2), 73-95. Google Scholar

Machin-Mastromatteo, J. D. (2012). Participatory action research in the age of social media: Literacies, affinity spaces and learning. New Library World. https:// doi.org/10.1108/03074801211282939

Marino, E. (2018). Sea Level Rise and Social Justice: The Social Construction of Climate Change Driven Migrations. In Climate Change and Its Impacts (pp. 181-193). Springer, Cham. https://doi.org/10.1007/978-3-319-77544-9_11

Martin, A., \& Grudziecki, J. (2006). DigEuLit: Concepts and tools for digital literacy development. Innovation in Teaching and Learning in Information and Computer Sciences, 5(4), 249-267. https://doi.org/10.11120/ital.2006.05040249

McKenzie-Mohr, D. (2008). Fostering sustainable behavior: beyond brochures. International Journal of Sustainability Communication, 3, 108-118. Google Scholar

Morganti, L., Pallavicini, F., Cadel, E., Candelieri, A., Archetti, F., \& Mantovani, F. (2017). Gaming for Earth: Serious games and gamification to engage consumers in pro-environmental behaviours for energy efficiency. Energy Research \& Social Science, 29, 95-102. https:// doi.org/10.1016/j.erss.2017.05.001

Morrison, K. (2017). The role of traditional knowledge to frame understanding of migration as adaptation to the "slow disaster" of sea level rise in the South Pacific. In Identifying emerging issues in disaster risk reduction, migration, climate change and sustainable development (pp. 249-266): Springer. https:// doi.org/10.1007/978-3-319-33880-4_15

Moser, S. C., \& Dilling, L. (2011). Communicating climate change: closing the scienceaction gap. The Oxford handbook of climate change and society, 161-174. Google Scholar

Nastis, S. A., \& Pagoni, E. G. (2019). Gamification of global climate change: an experimental analysis. Studies in Nonlinear Dynamics $\mathcal{E}$ Econometrics, 23(3). https:// doi.org/10.1515/snde-2017-0105

Nisbet, M. C. (2009). Communicating climate change: Why frames matter for public engagement. Environment: Science and Policy for Sustainable Development, 51(2), $12-$ 23. https://doi.org/10.3200/ENVT.51.2.12-23

Nor, R. M., \& Azhar, N. A. (2017). Applying Green Gamification to Support Green Campus Initiatives in Reducing Carbon Emissions. Computing Research $\mathcal{E}$ Innovation (CRINN) Vol 2, October 2017, 306. Google Scholar

Novakovich, J. (2016). Fostering critical thinking and reflection through blog-mediated peer feedback. Journal of Computer Assisted Learning, 32(1), 16-30. https:// doi.org/10.1111/jcal.12114

Olanrewaju, R. M., Tilakasiri, S. L., \& Bello, F. B. (2018). Community perception of deforestation and climate change in Ibadan, Nigeria. Journal of the University of Ruhuna, 6(1), 26. http://doi.org/10.4038/jur.v6i1.7866

Panis, I., Setyosari, P., Kuswandi, D., \& Yuliati, L. (2020). Design Gamification Models in Higher Education: A Study in Indonesia. International Journal of Emerging Technologies in Learning (iJET), 15(12), 244-255. Google Scholar

Pothitou, M., Hanna, R. F., \& Chalvatzis, K. J. (2016). Environmental knowledge, proenvironmental behaviour and energy savings in households: An empirical study. Applied Energy, 184, 1217-1229. https://doi.org/10.1016/j.apenergy.2016.06.017 
English for Specific Purpose: Revitalizing Climate Change Awareness Using Digital Literacy and Gamification for Engineering Faculty in Papua

Prihandoko, L. A. (2019). Energizing Students' Academic Writing Competence through Research Group Activity (A Supervisor Intervention). International Journal of Multicultural and Multireligious Understanding, 6(2), 589-596. http:/ / dx.doi.org/10.18415/ijmmu.v6i2.721

Prihandoko, L. A., \& Fitria, Y. P. (2017, 2017). The paradigm shift: the undergraduates" motive in entering graduate english education department program. Google Scholar

Prihandoko, L. A., Nurkamto, J., \& Marmanto, S. (2018, 2018). An Effort of Chemistry Graduate Students Publishing an Article in Scopus-indexed Journals. Google Scholar

Purnamadewi, Y. L., Orchidea, M. D., \& Mulatsih, S. (2019, 2019). Fiscal policy and environmental quality in Indonesia. Google Scholar

Rajanen, D., \& Rajanen, M. $(2019,2019)$. Climate change gamification: A literature review. Google Scholar

Reynolds, T. W., Bostrom, A., Read, D., \& Morgan, M. G. (2010). Now what do people know about global climate change? Survey studies of educated laypeople. Risk Analysis: An International Journal, 30(10), 1520-1538. https:// doi.org/10.1111/j.1539-6924.2010.01448.x

Rowsell, J., Burke, A., Flewitt, R., Liao, H. T., Lin, A., Marsh, J., . . . Wohlwend, K. (2016). Humanizing digital literacies: A road trip in search of wisdom and insight. The Reading Teacher, 70(1), 121-129. https:/ / doi.org/10.1002/trtr.1501

Ryan, R. M., Rigby, C. S., \& Przybylski, A. (2006). The motivational pull of video games: A self-determination theory approach. Motivation and emotion, 30(4), 344360. https:// doi.org/10.1007/s11031-006-9051-8

Sandvik, H. (2008). Public concern over global warming correlates negatively with national wealth. Climatic Change, 90(3), 333-341. https://doi.org/10.1007/s10584008-9429-6

Schuldt, J. P., \& Pearson, A. R. (2016). The role of race and ethnicity in climate change polarization: evidence from a US national survey experiment. Climatic Change, 136(3-4), 495-505. https:// doi.org/10.1007/s10584-016-1631-3

Sgueo, G. (2017, February). Gamification and Climate Change Activism: Beneficial or Detrimental?. In New York University Global Faculty Symposium Position Paper2017. Google Scholar

Shi, J., Visschers, V. H. M., Siegrist, M., \& Arvai, J. (2016). Knowledge as a driver of public perceptions about climate change reassessed. Nature Climate Change, 6(8), 759-762. https://doi.org/10.1038/nclimate2997

Socolow, R., Hotinski, R., Greenblatt, J. B., \& Pacala, S. (2004). Solving the climate problem: technologies available to curb $\mathrm{CO} 2$ emissions. Environment: Science and $\begin{array}{llll}\text { Policy for Sustainable Development, } & 46(10),\end{array}$ https:// doi.org/10.1080/00139150409605818

Susanto, A., Purwanto, P., Sunoko, H. R., \& Setiani, O. (2017). A kriging method for mapping underground mine air pollution. Advanced Science Letters, 23(3), 23292332. https:// doi.org/10.1166/asl.2017.8739

Tang, C. M., \& Chaw, L. Y. (2016). Digital Literacy: A Prerequisite for Effective Learning in a Blended Learning Environment? Electronic Journal of E-learning, 14(1), 54-65. Google Scholar

Tewari, P., Singh, P., \& Verma, D. (2019). A study on awareness of farm women regarding climate change and its coping strategies. Google Scholar

Tubman, M. (2015). President Obama's Climate Action Plan: Two Years Later. Center for Climate and Energy Solutions: Washington, DC, USA. Google Scholar 
English for Specific Purpose: Revitalizing Climate Change Awareness Using Digital Literacy and Gamification for Engineering Faculty in Papua

Van Deursen, A. J. (2010). Internet Skills: vital assets in an information society: Gildeprint. Google Scholar

Waxman, H. A., Rush, B. L., Blumenauer, E., Whitehouse, S., Cardin, B. L., \& Markey, E. J. $(2013,2013)$. Implementing the President's climate action Plan: US Department of the Interior. Google Scholarjj

Wee, S.-C., \& Choong, W.-W. (2019). Gamification: Predicting the effectiveness of variety game design elements to intrinsically motivate users' energy conservation behaviour. Journal of environmental management, 233, 97-106. https:// doi.org/10.1016/j.jenvman.2018.11.127

Wi, A., \& Chang, C.-H. (2019). Promoting pro-environmental behaviour in a community in Singapore-from raising awareness to behavioural change. Environmental Education Research, 25(7), 1019-1037. https:// doi.org/10.1080/13504622.2018.1528496

Yadav, S. S., \& Lal, R. (2018). Vulnerability of women to climate change in arid and semi-arid regions: The case of India and South Asia. Journal of Arid Environments, 149, 4-17. https:// doi.org/10.1016/j.jaridenv.2017.08.001

\section{Copyright Holder :}

(c) Betaubun M., \& Nasrawati N. (2020).

First Publication Right :

(c) Jurnal Iqra' : Kajian Ilmu Pendidikan

This article is under:

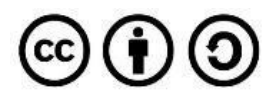

